\title{
THE EFFECTS OF CURRENCY CRISIS ON THE SHARE PRICESOF TURKISH ENERGY COMPANIES
}

\author{
KUR KRİZLERININ TÜRK ENERJI ŞİRKETLERINIIN HİSSE SENEDİ \\ FIYYATLARINA ETKILLEİ
}

\author{
Jale ORAN ${ }^{*}$ \\ Emre AYDOS ${ }^{* *}$ iD
}

\begin{abstract}
In developing countries, currency crises have become a significant threat. The purpose of the paper is to examine the volatility of stock prices during the two recent currency crises in Turkey. The selected companies are the 15 Turkish energy companies listed on the stock exchange.In an atmosphere where economic uncertainties are growing as a result of globalisation; the exchange rate is one of the most critical measures and costs. The aim of this study is to reveal its impact on stock prices of Turkish energy companies. The period of the study covers 12 quarterly periods between 31.03.2018 and 31.12.2020.A multiple regression model was used to investigate the impact of currency fluctuation on the stock prices of energy companies operating in Turkey.

Our empirical findings show that during the financial crisis, there was no significant relationship between stock prices and currency rates.
\end{abstract}

Keywords: Foreign Exchange, Foreign Exchange Policy, Crisis Management

JEL Classification:F31, O24, H12

Öz

Gelişmekte olan ülkelerde döviz krizleri önemli bir tehdit haline gelmiştir. Bu makalenin amacı, Türkiye’de son iki döviz krizi sırasında hisse senedi fiyatlarının oynaklığını incelemektir. Seçilen şirketler borsada işlem gören 15 Türk enerji şirketidir. Küreselleşmenin bir sonucu olarak ekonomik belirsizliklerin arttığ 1 bir ortamda döviz kuruen kritik önlem ve maliyetlerden biridir. Bu çalışmanın amacı, değişimlerin Türk enerji şirketlerinin hisse senedi fiyatları üzerindeki etkisini ortaya koymaktır. Çalışma dönemi 31.03.2018 ile 31.12.2020 tarihleri arasındaki 12 adet çeyreklik dönemi kapsamaktadır. Türkiye’de faaliyet gösteren enerji şirketlerinin hisse senedi fiyatlarındaki kur dalgalanmasının etkisini araştırmak için çoklu regresyon

* Prof. Dr., Marmara University, Faculty of Business Administration, İstanbul. E-Mail: jaleoran@marmara.edu.tr, ORCID ID: 0000-0001-8976-2893.

** PhD Student, Marmara University, Faculty of Business Administration, E-Mail: emreaydos@marun.edu.tr, ORCID ID: 0000-0003-2094-2655. 
modeli kullanılmıştır. Ampirik bulgularımız, finansal kriz sırasında hisse senedi fiyatları ile döviz kurları arasında anlamlı bir ilişki olmadı̆̆ını göstermektedir.

Anahtar Kelimeler: Döviz, Döviz Politikası, Kriz Yönetimi

JEL Sinıflandırması: F31, 024, H12

\section{Introduction}

A currency crisis means a speculative assault on a currency's exchange value that leads to an abrupt depreciation or obliges the governments to sell foreign-exchange reserves and increase national currency interest rates. The economic costs of currency crises are highly observable, but our ability to forecast the timing and severity of crises is constrained by our theoretical understanding of the dynamic interactions between macroeconomic fundamentals, market perceptions and government policies.

Appropriate hedging strategies can be utilized to minimize the effect of the currency crisis. Since it has no recognizable cash position in the underlying currency, a company can hedge by trading in a specific future, forward, or option market.

Since both play a crucial role in the economic growth of an economy, the relationship between stock prices and exchange rates is significant. Relations between stock prices and exchange rates may have an impact on the implementation of monetary policy and fiscal policy. The weakening of exchange rates can stimulate exports and can weaken the stock market at the same time.

In the Turkish economy, there have been four instances of currency crises over the years (Yokuş and Ay, 2020). This research focuses on the 2018 financial crisis. It was characterized by the plunging value of the Turkish lira, high inflation, rising borrowing rates, and correspondingly rising defaults on loans. The crisis has been triggered by the excessive current account deficit of the Turkish economy and significant sums of private foreign currency denominated debt. Some observers also emphasize the leveraging effects on some Turkish goods such as steel and aluminum, creating the geopolitical frictions with the United States and trigger newly imposed tariffs by the Trump administration.

From March to October of 2017, Turkey's thirty-year foreign economic relations have followed the same pattern: The domestic bourgeoisie exports capital to the outside world, and the external financing requirement is met by foreign capital inflows. However, the picture has completely changed in the first eight months of 2018. A sharp decline in foreign capital inflows, combined with an increase in domestic capital exports, resulted in net capital outflows (Boratav, 2018).

Despite achieving 7.4 percent economic growth in 2017, Turkey's interest rates began to fluctuate as credit opportunities became more difficult in the international arena. Because the government's borrowing limit had been exceeded, domestic interest rates were higher, and the Turkish Lira was depreciating rapidly in comparison to previous years. These losses do not appear to be comparable to those experienced in 2018 , when the lira lost $41 \%$ of its value against the US dollar in the first eight months. However, it should be noted that the lira depreciated by 20.5 percent against the US dollar between July 2016 and the end of 2017 (Güngen, 2018). 
Turkey faces a greater risk of economic collapse as a result of the currency crisis, which is the country's second in less than two years, combined with the pandemic. The Turkish lira has consistently reached new lows against the US dollar. With the assistance of the Covid-19 pandemic, Turkey's currency lost 30 percent of its value this year alone.

During the past few years, the energy market has seen major fluctuations as supply and demand have shifted rapidly. The problems of sustainability and renewables, meanwhile, remain an ongoing debate. As the industry evolving so rapidly, it is more critical than ever that companies remain up to date on the fluctuations of foreign currencies. Foreign exchange should never be an afterthought, whether making or accepting payments. As a part of every deal, it should be budgeted for. If the exchange rate changes unfavorably on the day a payment is made or received, the negotiated rates and calculated profits can be greatly affected.

To check the relationship between stock prices and exchange rates, a variety of studies have been performed using various methodologies and datasets, but the findings have been mixed. In addition, most of this research has been conducted for periods when the stock markets operate under normal conditions. It would be interesting to check whether or not transfers between two asset markets, namely the foreign exchange market and the equity market, behave differently during crisis periods compared to normal ones. When asset markets are in crisis, the returns will be lower and the volatility higher, as well as the correlation between asset markets tends to be higher.

\section{Literature Review}

The contradictory results of the studies on the relationship between stock prices and exchange rates in the financial literature have caused this issue to remain up-to-date and to be at the centre of attention. A study by Ding (2021) demonstrates that the exchange rate - stock price correlation was negative in 1990s while it turned out to be positive after 2001 crisis. Gökmenoğlu, Eren and Haşemi’s study (2021) is between exchange rates and stock returns covers 8 emerging markets including Turkey. The results reveal that stock market returns are affected under certain market conditions, markets being bullish or bearish. This also means that the relationship is asymmetrical. Pan, Fok and Lio (2007) found out that there is significant causal relation from exchange rates and stockprices for 4 Asian markets, Hong Kong, Japan, Malesia and Thailand. Before 1997 crisis. Ali and Sun (2017) investigated some South Asian Countries' markets. They found out long run relationship between equity market and foreign exchange market in India, and one-way causal relation from equity market to stock market in Pakistan during 2009-2015 period. In an emerging economy such as the Turkish market, with its only equity exchange, Borsa İstanbul (BIST), it became crucial to investigate the relationship between stock prices and the exchange rate.

The risks facing an energy producer have two components. One is the risk associated with the energy market price named as price risk; the other is the risk associated with the quantity of energy to be purchased referred to as volume risk (Hull, 2018). In addition to these two threats, currency risk is evident in companies operating in highly competitive emerging markets. Decisions to use foreign 
currency credit can induce financial risk in order to reduce financial expenses. International debt continues to be used both for hedging purposes and for speculative purposes that isto lower debt costs (Gatopoulos and Loubergé, 2013).

The main business of an energy company is to buy primary energy sources on (mostly) global and U.S. dollar denominated markets, turn them into electricity, and sell electricity on local energy markets. Therefore, they face an exchange rate risk between goods that they mostly buy in U.S. dollars, and energy that is typically sold in local currency. In the supply and demand sides, companies often have an exposure due to commodity prices when they purchase primary energy sources such as oil or gas and sell electricity. Lastly, it's extremely costly to build power plants. Projects in the energy industry are also typically not solely funded by equity but require large amounts of debt. Since interest rates are not usually completely set in debt contracts, there is an interest rate risk for utilities (Lievenbrück and Schmid, 2014).

We may summarize that there are two ways to interpret the complex relationship between stock prices and exchange rates. On the one side, as suggested by Dornbusch and Fischer (1980), the "floworiented" models of exchange rates concentrate on the current account balance or the trade balance. As stock prices can be viewed as the present value of firms' potential cash flows, they respond to changes in exchange rates. Real exchange rate directly influences the real stock price. The depreciation of the real exchange rate will increase firms' export competitiveness in terms of lower prices and will increase their competitiveness in terms of prices. Higher exports, greater income for the businesses. The values and stock prices of companies would be improved by this. Therefore, the real exchange rate depreciation will raise the real stock price, while the real exchange rate appreciation will decrease the real stock price.

On the other hand, the "stock-oriented" exchange rate models, as suggested by Branson (1983) and Frankel (1983) argue that stock market developments influence aggregate demand through effects on wealth and liquidity, thus affecting money demand. A fall in stock prices, for instance, leads to reduced domestic investor capital and, in turn, lower money demand with resulting lower interest rates. Subsequently, the lower interest rates deter capital inflows, ceteris paribus, which induces currency depreciation and thus, exchange rate dynamics can be affected by stock price movements. The real price of stocks determines the real exchange rate. A bull stock market would draw capital inflows for investment in the stock market from abroad. In the stock market, this would boost demand for stocks. Higher equity demand will raise stock prices, and real exchange rates will be appreciated by inflows of capital from abroad for investment in the stock market. In addition, an increase in stock prices would lead to a rise in the net worth of businesses. Companies will increase their production and distribution. This will boost the economy's aggregate demand, which will increase interest rates and draw further capital inflows from abroad. Bear stock market would lead to depreciation of real exchange rate.

The Johansen Cointegration Test shows the presence of a long-term relationship between the exchange rate and each stock price. As a result, it is shown that only the exchange rate and the 
Service Sector Index do not have a long-term relationship. According to the Granger causality study of Hsiao (1981), the causality relationship was calculated, and it was found that bilateral causality exists between the exchange rate and the National 100 Index, the Exchange Rate Financial Sector Index and the Exchange Rate Industry Sector Index. Some study in the literature is supported by this outcome (Ayvaz, 2006).

The correlation between exchange rates and stock prices becomes stronger during crisis periods than during normal periods, in terms of long-term co-integration and short-term causality consistent with contagion, or spill over during the crisis times between exchange rates and stock prices. Moreover, it has emerged that most of the spill overs can be traced to the channel that runs from stock price shocks to exchange rates, coinciding with the statement that an economy's recession affects stock prices, thus causing foreign investors to withdraw their money, placing downward pressure on the currency (Lin, 2012).Lien points out an interesting phenomenon, that is the spillovers are not always among neighbor countries, but even towards distant markets in other continents (Lien, Lee, Yang and Zhang, 2018).

Turkish banks' negative pre-event returns could signal the anticipation of an upcoming crisis in Turkey, better and earlier expected in the local market than in other countries. The findings reflect the feeling of investors that banks will be immune to future bank defaults with spillover effects. The stocks of the overall banking sample respond negatively to the crisis in Turkey and the results indicate that banks which have recently increased their leverage or experienced a decrease in profitability have also suffered higher abnormal losses on the day and the day after the case, where the losses have been the most serious in general. Nonetheless, the leverage, liquidity and efficiency ratios alone are not adequate for the financial soundness of banks to be measured, as the risk is more related to the nature of the assets, they carry than to the quantity of assets they carry (Arbaa and Varon, 2019).

\section{Empirical Analysis}

The data used in the research covers 12 periods (Table 1), including the end of each quarter of 2018, 2019 and 2020. The USD and Euro exchange rates, including 12 quarters, are taken from the Central Bank of the Republic of Turkey's website. The stock prices (SP) of 15 companies operating in the Turkish energy sector and in Borsa Istanbul Indices (BIST) are taken from Thomson Reuters Refinitiv Eikon for each quarter. Central Bank Interest Rates (INT) for 12 quarters are also taken from Central Bank of the Republic of Turkey's website.

The quarterly changes in USD (USDC), Euro (EUROC) and BIST (BISTC) index values compared to the previous quarter were taken and used as independent variables.Compared to time-series and cross-sectional data, panel data is more insightful and produces more efficient results. To investigate the impact of four independent variables on the dependent variable, a multiple regression model was used (Yerdelen-Tatoğlu, 2020).

The average rise in the US dollar in the examined timeframe is about 6 percent relative to the Euro, as can be seen in Table 1. During the times we call the crisis, we have noted that the exchange rate in 
both currencies has risen from the Turkish Lira by 28 per cent in terms of US dollars and 25 per cent in terms of the euro. In that time, the average value of the stocks of companies operating in the energy sector increased by 13 per cent and the Borsa Istanbul index remained at an average rate of 3 per cent. The fact that both exchange rates have risen by one hundred percent relative to the minimum prices over a period of two years illustrates how conservative financial management should be for energy companies that have investment costs in terms of foreign currency.

Table 1: Descriptive Statistics

\begin{tabular}{|l|l|l|l|l|l|}
\hline Variable & Obs. & Mean & Std. Dev. & Min & Max \\
\hline SP & 180 & 11.07299 & 26.37918 & .48 & 143.5 \\
\hline SPC & 180 & .1357574 & .4542192 & -.5164761 & 3.445455 \\
\hline USD & 180 & 5.842374 & 1.076004 & 3.818283 & 7.875797 \\
\hline USDC & 180 & .0663522 & .0853374 & -.0340912 & .2782788 \\
\hline Euro & 180 & 6.690705 & 1.228724 & 4.692058 & 9.388966 \\
\hline EuroC & 180 & .0657123 & .0806074 & -.0433654 & .246924 \\
\hline BIST & 180 & 1067.308 & 156.3164 & 896.44 & 1476.72 \\
\hline BISTC & 180 & .0312454 & .1479191 & -.2165698 & .2998639 \\
\hline INT & 180 & .1629167 & .0628565 & .08 & .24 \\
\hline
\end{tabular}

If the coefficient of correlation is around zero, the existence of a weak relationship between variables is indicated. If the variables rise or decrease together, there is a positive relationship, and a negative relationship if one of the variables rises and the other decreases. As shown in Table 2, the variable that has the strongest relationship to changes in the stock price over the 12 quarters of 2018-2020 is the change in the BIST index. The volatility in the euro and the US dollar exchange rate is seen to be moderately linked to share prices. In fact, the impact of the policy interest rate on stock prices is seen to be more than exchange rate volatility. It is also shown that exchange rates influence the Borsa Istanbul general index more than the shares of these 15 energy firms.

Table 2: Correlation Matrix

\begin{tabular}{|l|l|l|l|l|l|}
\hline & SPC & USDC & EuroC & BISTC & INT \\
\hline SPC & 1.0000 & & & & \\
\hline USDC & -0.0307 & 1.0000 & & & \\
\hline EuroC & 0.0284 & 0.9522 & 1.0000 & & \\
\hline BISTC & 0.5725 & 0.0968 & 0.1703 & 1.0000 & \\
\hline INT & -0.3441 & 0.1572 & -0.0153 & -0.1097 & 1.0000 \\
\hline
\end{tabular}

To measure the relationship and build the model, more than one independent variable was used (Çakmur-Yıldırtan, 2017). The group of independent variables except USDC show a statistically significant relationship with the dependent variable. As it could be seen on Table 3, however, .056 is so close to .05 that it can be considered as statistically significant.For every unit increase in USDC, a 2.362356 unit increase in SPC is predicted, holding all other variables constant. In other words, for every one-pointincrease of SPC, USDC is predicted to be higher by .3893102 points. This is significantly different from 0 . 
Interest Rate Change (INT) and BIST Change (BISTC) are the most significant independent variables.Positive relationship between BISTC and stock prices operating in energy sector is seen on Table 3. On the contrary, the relationship is negative between INT and stock prices of energy companies.

Table 3: Regression Results

\begin{tabular}{|l|l|l|l|l|}
\hline Variables & Coefficient & $\mathbf{t}$ & $\mathbf{P}>|\mathbf{t}|$ & Stand.Error \\
\hline USDC & 2.362356 & 1.92 & 0.056 & 1.229847 \\
\hline EuroC & -2.804088 & -2.16 & 0.032 & 1.296064 \\
\hline INT & -2.590551 & -5.17 & 0.000 & 0.5011301 \\
\hline BISTC & 1.765557 & 9.64 & 0.000 & .1830567 \\
\hline cons & .5301513 & 5.99 & 0.000 & .0885498 \\
\hline
\end{tabular}

As can be seen from the Graph 1, a significant fall in the stock prices of the companies surveyed, was observed at the end of the first quarter because of the foreign exchange and financial crises faced in Turkey due to the effects of the pandemic in 2020. During the crisis in 2018, we can talk about a similar impact. Turkey's effect of the crisis on the stock market has been profoundly encountered in private as opposed to 2018 due to global problems experienced in 2020. The macroeconomic situation in Turkey was also included as a factor among the reasons for the poor results. We see, however, that the increase in stock prices diverged positively from the 2018 exchange rate crisis. Although the exchange-rate rise has not dropped at the same amount, the increase in stock prices indicates the Table 2 results.

Graph 1: Stock Prices Change

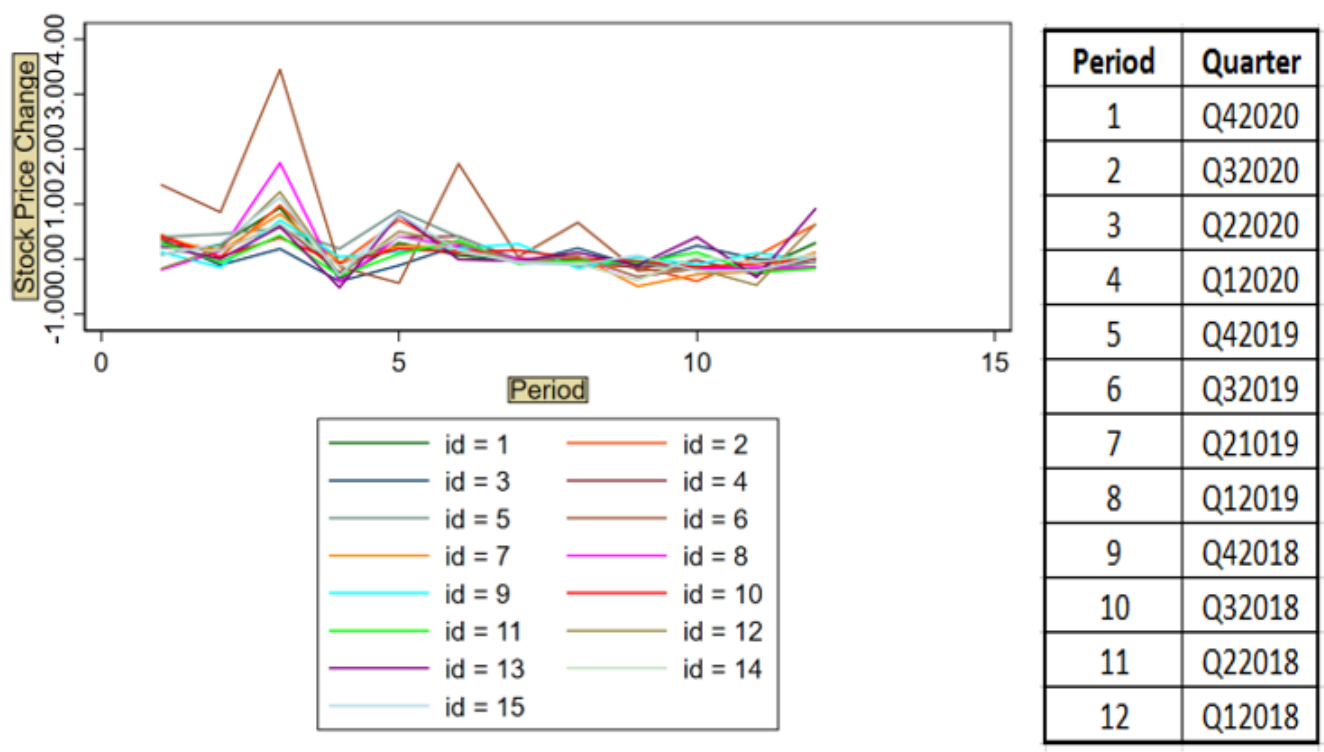


When we analyse the change of the value (Graph 2) of the US dollar against Turkish Lira during these periods, we can conclude that there was a much higher volatility compared to stock prices. We may assume that this situation we have found for the US Dollar is also true for the Euro, based on the high correlation between them. Although there was a 30 percent rise in the exchange rate in 2020, no decline in the stock prices of the companies analysed was observed at this stage. It is possible to analyse whether the difference in question is related to the financial structures of companies or to the risk perception of investors in another study.

\section{Graph 2: USD/TRY Parity}

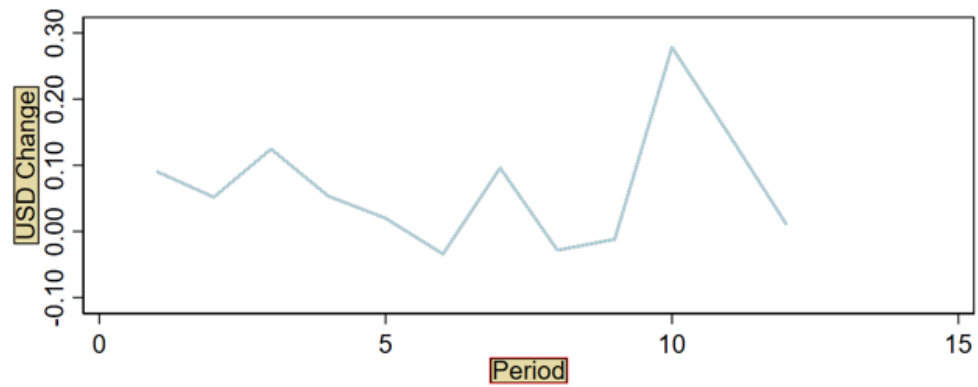

It was found that the stock prices of the companies operating in the energy sector that we analysed responded differently during the two periods in which excessive exchange rate fluctuations occurred. During the exchange rate fluctuation at the beginning of the pandemic, the losses in the stock prices of companies operating in the energy sector were seen to have remained lower than the losses in the BIST index.

\section{Graph 3: BIST Change}

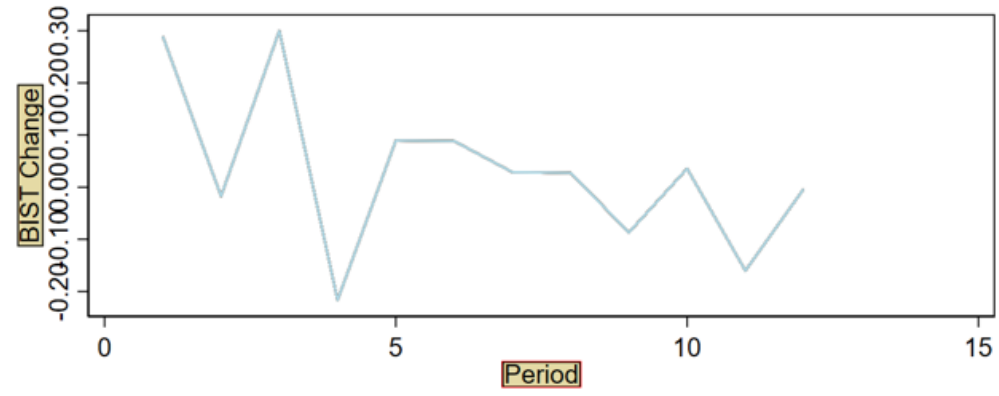

\section{Conclusion}

The relationship between exchange rates and stock prices in the Turkish energy market has been explored in this study. In order toanalyze how short-term relationship is affected by such events, 
we have chosen to include in the study the major financial changes in Turkish financial market during financial crisis. Our empirical findings indicate that the relationship between stock prices and exchange rates during the financial crisis is not significant.

In the last two financial crises of the Turkish economy, we may say that volatility in stock prices are not at the same degree as exchange rate volatility for companies operating in the energy sector.

The purpose of analyzing quarterly results, rather than daily, weekly, or monthly data, was to exclude the effect of short-term shocks. It was desired to observe the long-term effects prior to the effect of short-term volatility. According to the results of this study, it is understood that, to analyze exchange rate crises and stock returns in more detail, it is also necessary to examine them in a shorter time rather than a quarter. For this reason, the price movements of the stocks to be selected in the next study will be achieved by obtaining price movements 5 days before and after the onset of the exchange rate crisis.

\section{References}

Ali M. \& Sun G. (2017). Dynamic relations between stock price and exchange rate: Evidence from South Asia. International Journal of Economics and Financial Issues, 7(3), 331-341.

Arbaa, O. \& Varon, E. (2019). Turkish currency crisis - Spillover effects on European banks. Borsa Istanbul Review, 19(4), 372-378.

Ayvaz, Ö. (2006). Döviz kuru ve hisse senetleri fiyatları arasındaki nedensellik ilişkisi. Gazi Üniversitesi İktisadi Ve İdari Bilimler Fakültesi Dergisi, 8(2), 1-14.

Branson, W. H. (1983). A model of exchange-rate determination with policy reaction: Evidence from monthly data. NBER Working Paper 1135, 2-35.

Boratav, K. (2018). Sermaye hareketleri ve Türkiye’nin beş krizi. Çalışma Ve Toplum Dergisi, 2019(1), 311-324.

Çakmur-Yıldırtan, D. (2017). E-Views uygulamalı temel ekonometri. Türkmen Kitabevi

Ding, L. (2021). Conditional correlation between Exchange rates and stockprice. The Quarterly Review of Economics and Finance, 80, 452-463.

Dornbusch, R. \& Fischer, S. (1980). Exchange rates and the current account. American Economic Review, 70(5), 960-971.

Frankel, J.A. (1983) Monetary and portfolio-balance models of exchange rate determination, economic interdependence and flexible exchange rates. MIT Press, 84-115.

Gatopoulos, G. \& Loubergé, H. (2013). Combined use of foreign debt and currency derivatives under the threat of currency crisis: The case of Latin American firms. Journal of International Money and Finance, 35, 54-75.

Gökmenoğlu, K., Eren B.M., Haşemi S. (2021). Exchange rates and stock markets: New evidence using the quantile-to-quantile approach.Quantitative Finance and Economics, 5(1), 94-110.

Güngen, A. R. (2018). Türkiye’ nin 2018 krizi: Nereden nereye?. MülkiyeDergisi, 42(3), 449-452.

Hsiao, C. (1981). Autoregressive modeling and money-income causality detection. Journal of Monetary Economics, 7, 85-106.

Hull, J. (2018). Options, futures and other derivatives. Pearson Education Limited.

Lin, C-H. (2012). The comovement between exchange rates and stock prices in the Asian emerging markets. International Review of Economics and Finance, 22, 161-172. 
Lien, D., Lee G., Yang L. \& Zhang Y. (2018). Volatility spillovers among the U.S. and Asian stock markets: A comparison between the periods of Asian currency crisis and subprime credit crisis. North American Journal of Economics and Finance, 46, 187-201.

Lievenbrück, M. \& Schmid, T. (2014). Novel evidence on cultural influence. Journal of Corporate Finance, 25, 92-106.

Pan, M-S, Fok R.C-W \& Lio Y.A. (2007). Dynamic linkages between exchange rates and stock prices: Evidence from East Asian markets. International Review of Economics and Finance, 16(4), 503-520.

Yerdelen-Tatoğlu, F. (2020). Panel veri ekonometrisi. Beta Yayınları.

Yokuş, T. \& Ay, A. (2020). Kur krizleri ve Türkiye: 2006-2018 dönemi. Yönetim Ve Ekonomi Araştırmaları Dergisi, 18(1), 295-316. 